Original Research Paper

\title{
Pengelolaan Sampah Melalui Pendidikan Kesadaran Bersih Lingkungan Sebagai Strategi Mitigasi Bencana di Desa Seriwe
}

\author{
Aftina Rabbani $^{1^{*}}$, Annisa Sabrina ${ }^{1}$, Arfaigah $^{1}$, Ayu Larasati ${ }^{1}$, Dita Kusnulyaningsih ${ }^{1}$, Qanita Handayani ${ }^{1}$

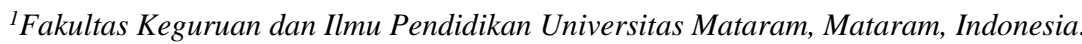

https://doi.org/10.29303/jpmpi.v3i2.1286

Sitasi: Rabbani, A., Sabrina, A., Arfaigah., Larasati. A., Kusnulyaningsih, D \& Handayani, Q. (2021). Pengelolaan Sampah Melalui Pendidikan Kesadaran Bersih Lingkungan Sebagai Strategi Mitigasi Bencana di Desa Seriwe. Jurnal Pengabdian Magister Pendidikan IPA, 5(1)

\section{Article history}

Received: 31 Desember 2021 Revised: 01 Februari 2022 Accepted: 05 Februari 2022

*Corresponding Author: Aftina Rabbani, Fakultas Keguruan dan Ilmu Pendidikan

Universitas Mataram, Mataram, Indonesia;

Email: tinaaftina@gmail.com

\begin{abstract}
Penumpukan sampah secara terus-menerus akan menyebabkan pencemaran yang akan memberi dampak buruk bagi lingkungan serta kehidupan manusia disekitarnya. Pelaksanaan Sosialisasi Pendidikan Kesadaran sampah diperlukan untuk meningkatkan kesadaran masyarakat terhadap kebersihan lingkungan agar dapat menciptakan lingkungan yang bersih dan nyaman serta dapat menghindari akan terjadinya kerugiankerugian akibat lingkungan yang kotor di masa mendatang. Metode yang digunakan dalam pelaksanaan sosialisasi ini adalah metode penyuluhan, Diskusi dan Aksi Lapangan. Umumnya masyarakat belum memahami cara mengelola sampah dengan baik, namun dengan adanya Sosialisasi tersebut masyarakat lebih memahami alternatif pengelolaan sampah, penyediaan bank sampah, dan pemilahan jenis sampah yang dapat mengurangi dampak bencana yang ditimpulkan karena faktor sampah sehingga masyarakat merespon positif dengan dilaksanakannya kegiatan ini. Sehingga kegiatan ini bermanfaat menambah pengetahuan masyarakat serta membentuk lembaga koordinasi untuk keberlanjutan program Pengelolaan Sampah di Desa Seriwe, Jerowaru Lombok Timur.
\end{abstract}

Keywords: Biogas; Pengelolaan Sampah, TPS 3R.

yaitu Sampah organik dan sampah anorganik. Sampah organik adalah sampah yang didalamnya terkandung senyawa-senyawa organik, tersusun dari unsur-unsur seperti $\mathrm{C}, \mathrm{H}, \mathrm{O}, \mathrm{N}$ dan lainnya, Sampah jenis ini umumnya mudah terurai secara alami oleh mikroorganisme, contohnya: sisa makanan, karton, kain, karet, kulit, sampah halaman dll. Sampah anorganik adalah sampah yang bahan kandungannya bersifat anorganik dan umumnya sulit terurai oleh mikroorganisme. Contohnya: kaca, kaleng, alumunium, debu, dan logam lainnya. (S. Hadiwiyoto 1983). Dari pengertian diatas dapat disimpulkan bahwa sampah adalah limbah padat yang tidak dapat digunakan atau dimanfaakan kembali dikarenakan telah dimanfaatkan sebelumya dan dibagi menjadi 2 (dua) jenis berdasarkan tingkat penguraiannya, yaitu sampah organik (sampah yang mudah terurai) dan sampah anorganik (sampah yang sulit terurai). 
Penumpukan sampah secara terus-menerus, baik sampah organik maupun anorganik akan menyebabkan pencemaran yang akan memberi dampak buruk bagi lingkungan serta kehidupan manusia disekitarnya. Terdapat 3 dampak buruk utama sampah terhadap manusia dan lingkungan yaitu Dampak Terhadap Kesehatan, Dampak Terhadap Lingkungan, dan Dampak Terhadap Keadaan Sosial dan Ekonomi. 1. Dampak Terhadap Kesehatan: Sampah dapat berdampak terhadap kesehatan apabila tempat dan pengelolaan sampah buruk berbagai hewan dan organisme yang dapat menjangkit berbagai penyakit seperti diare, kolera, tifus, demam berdarah (haemorhagic fever), jamur, dll akan muncul. 2. Dampak Terhadap Lingkungan: dikarenakan penumpukan dan pengelolaan sampah yang buruk berbagai flora dan fauna dapat terancam mati atau punah, serta menyebabkan kerusakan pada unsur-unsur alam seperti terumbu karang, tanah, perairan hingga lapisan ozon yang akan merusak berbagai ekosistem biologis yang ada dilingkungan-lingkungan yang dipenuhi sampah tersebut. 3. Dampak Terhadap Keadaan Sosial dan Ekonomi: Sampah dapat berdampak terhadap Keadaan Sosial dan Ekonomi dipengaruhi oleh 2 dampak buruk sampah yang telah dijabarkan diatas, masalah kesehatan karena sampah akan meningkatkan biaya pengobatan rumah sakit, dan masalah lingkungan akan menyebabkan tingginya biaya yang diperlukan untuk membangun infrastuktur yang dapat mengelola sampah dengan baik agar tidak adanya permasalahan lingkungan lain yang disebabkan oleh sampah. (Gelbert M, Prihanto D dan Suprihatin A, 1996)

Salah satu cara yang dapat dilakukan oleh masyarakat untuk berperan serta dalam pengelolaan sampah adalah dengan cara menerapkan prinsip 4R, yakni reduce (mengurangi), reuse (penggunaan kembali), recycle (daur ulang) dan replace (mengganti) serta melakukan pemilahan sampah organik dan anorganik (Chandra Wahyu Purnomo, 2020). Reduce (mengurangi) memiliki arti usaha untuk meminimalisir produksi sampah misalkan dengan cara mengurangi penggunaan Styrofoam dan menggantinya dengan kertas atau plastik yang lebih mudah untuk di daur ulang karena Styrofoam adalah bahan yang tidak dapat di daur ulang. Selain itu, mengurangi sampah juga dapat dilakukan dengan membawa sendiri tas belanja yang bisa digunakan kembali saat berbelanja sehingga dapat mengurangi sampah plastik. Reuse (penggunaan kembali) yaitu dengan menggunakan kembali, sebisa mungkin pilihlah barang-barang yang bisa digunakan kembali seperti wadah-wadah botolbotol bekas, kaleng, dan galon. Recycle (daur ulang) adalah mengubah sampah menjadi sesuatu yang bermanfaat seperti mebuat wadah bekas cat menjadi pot tanaman, mmembuat pupuk kompos dari sampah organik ataupun produk kreatif lainnya. Replace (mengganti) ialah mengganti bahan yang ada dengan bahan yang lebih ramah lingkungan seperti mengganti plastik sampah sekali pakai dengan keranjang sampah yang dapat digunakan berkali-kali. Selain menerapkan prinsip 4R, masyarakat juga dapat memisahkan sampah organik dan sampah anorganik untuk kemudian di kirim ke bank sampah untuk dikelola lebih lanjut oleh ahlinya.

Berdasarkan hasil survei yang dilakukan oleh mahasiswa KKN Universitas Mataram, permasalahan mengenai sampah di Desa Seriwe ini disebabkan oleh tingkat kesadaran bersih lingkungan masyarakat di Desa Seriwe ini masih tergolong rendah. Banyak ditemukan tumpukan sampah di sekitar lingkungan tempat tinggal dan pinggiran pantai. Bersumber dari hasil wawancara yang dilakukan dengan kepala dusun setempat, hal ini terjadi karena masyarakat tidak memiliki tempat untuk membuang sampah atau Tempat Pembuangan Sampah Sementara (TPS). Penumpukan sampah di pinggiran pantai selain berasal dari masyarakatnya sendiri, juga disebabkan oleh sampah yang terbawa arus gelombang laut. . Laut yang ada di Desa Seriwe ini merupakan teluk, sehingga sampah dari daerah lain terbawa arus dan malah bermuara di pantai Desa Seriwe. Selain itu, dikarenakan posisi Desa Seriwe yang terletak cukup jauh dari ibu kota, yaitu terletak di bagian ujung selatan pesisir Lombok Timur, maka hal ini menyebabkan sulitnya kendaraan pengangkut sampah untuk menjangkau daerah tersebut, sehingga masyarakat menangani sampah dengan cara membakarnya atau membuang sampah di pantai. Untuk itu diadakan kegiatan yang bertujuan untuk meningkatkan kesadaran masyarakat mengenai kebersihan lingkungan. Sebagai bentuk usaha mewujudkan kesadaran bersih lingkungan dalam masyarakat, mahasiswa KKN Universitas Mataram mengadakan kegiatan sosialisasi yang diharapkan dapat meningkatkan kesadaran masyarakat terhadap kebersihan lingkungan agar dapat menciptakan lingkungan yang bersih dan 
nyaman serta dapat menghindari akan terjadinya kerugian-kerugian akibat lingkungan yang kotor di masa mendatang.

\section{Metode}

\section{Waktu dan tempat}

Kegiatan Kuliah Kerja Nyata (KKN) ini telah dilaksanakan pada tanggal 29 November-6 Januari 2021 di Desa Seriwe, Kecamatan Jerowaru, Lombok Timur.

\section{Persiapan}

Tahapan persiapan melalui program yang telah dilakukan oleh kelompok Kuliah Kerja Nyata (KKN) di Desa Seriwe diantaranya meliputi:

1. Sosialisasi kepada masyarakat tentang pengelolaan sampah sebagai upaya edukasi bencana di Desa Seriwe

2. Koordinasi dengan pihak Dinas Lingkungan Hidup dan Kebersihan (LHK) sebagai pemateri sosialisasi serta koordinasi dengan pemerintah desa

3. Persiapan materi sosialisasi tentang pengelolaan sampah sebagai upaya edukasi bencana untuk meningkatkan kesadara masyarakat dalam menjaga lingkungan hidup di Desa Seriwe

4. Observasi lokasi sosialisasi pendidikan bersih lingkungan

Alat dan bahan:

1. Sound system

2. Laptop

3. Banner

4. Konsumsi

\section{Pelaksanaan}

Pelaksanaan sosialisasi pengelolaan sampah sebagai upaya edukasi bencana di Desa Seriwe, Kecamatan Jerowaru.

Metode yang digunakan dalam pelaksanaan sosialisasi ini adalah metode penyuluhan, Diskusi dan Aksi Lapangan. Kegiatan ini berlangsung pada Senin, 20 Desember 2021 pukul 15.00 WITA bertempat di Kantor Desa Seriwe dengan dihadiri oleh Kepala Desa, Staf kantor desa, Karang taruna, masyarakat setempat, dan kelompok mahasiswa Kuliah Kerja Nyata (KKN). Kegiatan sosialisasi ini menggundang narasumber dari pihak Dinas Lingkungan Hidup dan Kebersihan (LHK) dengan menyampaikan materi tentang pengelolaan sampah melalui bank sampah dan TPS $3 \mathrm{R}$ sebagai upaya edukasi bencana untuk meningkatkan kesadaran masyarakat dalammenjaga lingkungan hidup di Desa Seriwe.

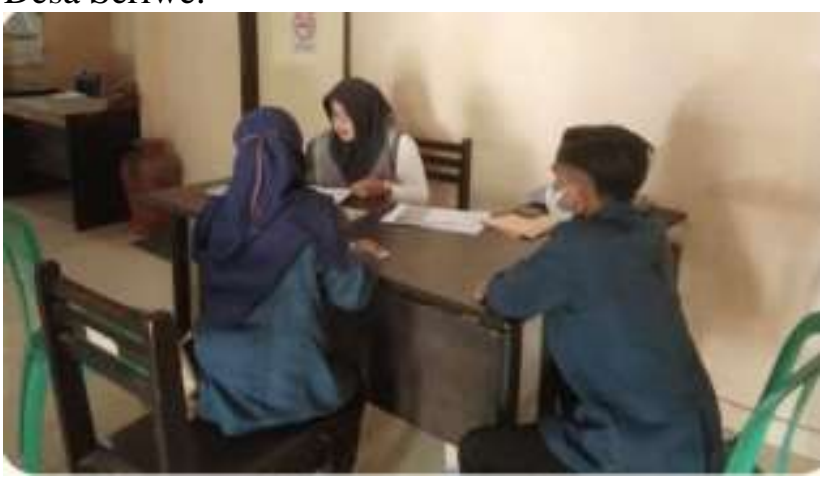

Gambar 1. Koordinasi dengan pihak LHK sebagai pemateri Sosialisasi

\section{Evaluasi}

Evaluasi dilakukan dengan memantau perilaku masyarakat setelah dilakukan sosialisasi oleh Dinas Lingkungan dan mengunjungi masyarakat desa serta membantu masyarakat memanfaatkan sampah botol plastik salah satunya sebagai alat untuk panen rumput laut.

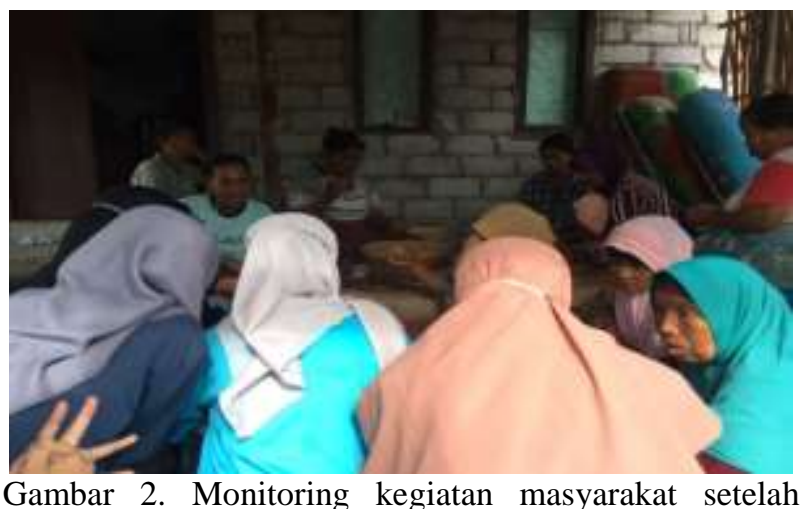
diadakannya sosialisasi

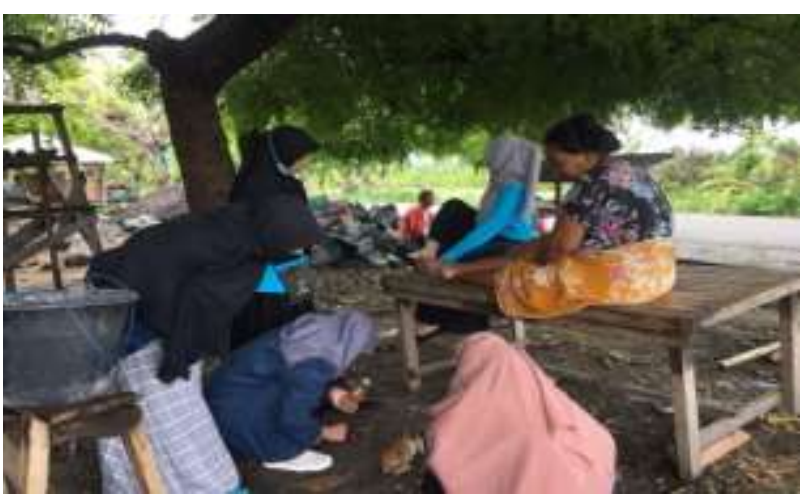


Gambar 3. Monitoring kegiatan masyarakat setelah diadakannya sosialisasi

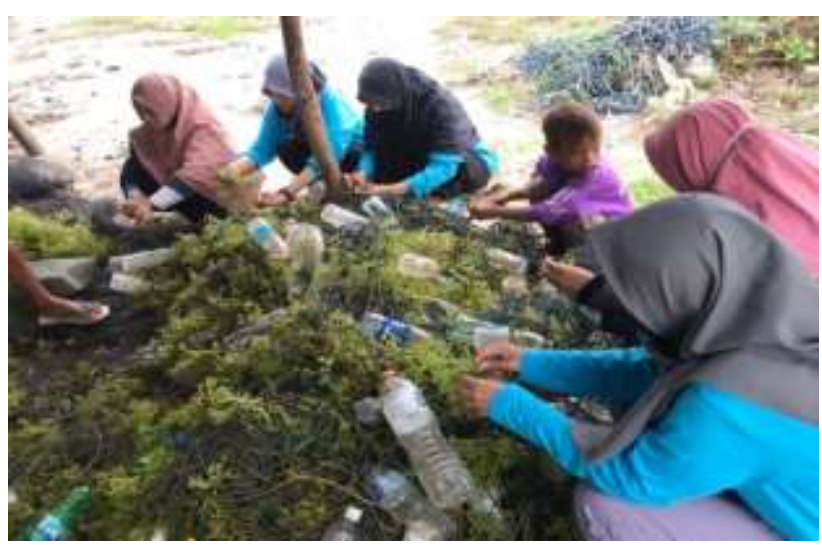

Gambar 4. Membantu masyarakat memanfaatkan sampah botol plastik sebagai alat panen rumput laut.

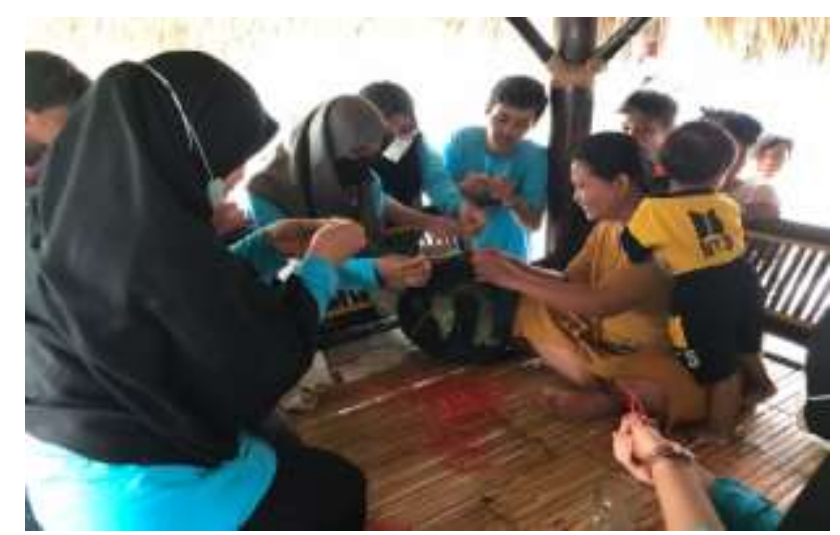

Gambar 5. Membantu masyarakat memanfaatkan sampah plastik sebagai alat panen rumput laut.

\section{Hasil dan Pembahasan}

\section{Sosialisasi Pengelolaan Sampah}

Kegiatan sosialisasi pengelolaan sampah dilaksanakan di Desa Seriwe dengan pelaksana kegiatan yaitu Kelompok KKN, yang menjadi motor penggerak dari pengolahan sampah yang ada di wilayah. Partisipasi masyarakat cukup antusias dengan dihadiri sebanyak 45 orang. Sosialisasi tersebut disampaikan dengan metode penyuluhan yang meliputi materi Pengelolaan Sampah melalui bank sampah dan TPS 3R, Jenis Sampah yang di tampung Bank Sampah,manfaat yang diperoleh dari pengelolaan sampah melalui Biogas maupun Pupuk Organik,Pihak yang terlibat dalam program tersebut, serta Alur mengajukan Bantuan kepada Dinas Lingkungan Hidup dan Kebersihan. Tahap Selanjutnya adalah koordinasi yang dilakukan dalam bentuk diskusi bersama pihak yang terlibat seperti Kepala Desa, Kelompok KKN, Tokoh masyarakat, serta pemuda setempat dalam menindaklanjuti kegiatan tersebut agar berjalan efektif dalam pelaksanaannya di lapangan.

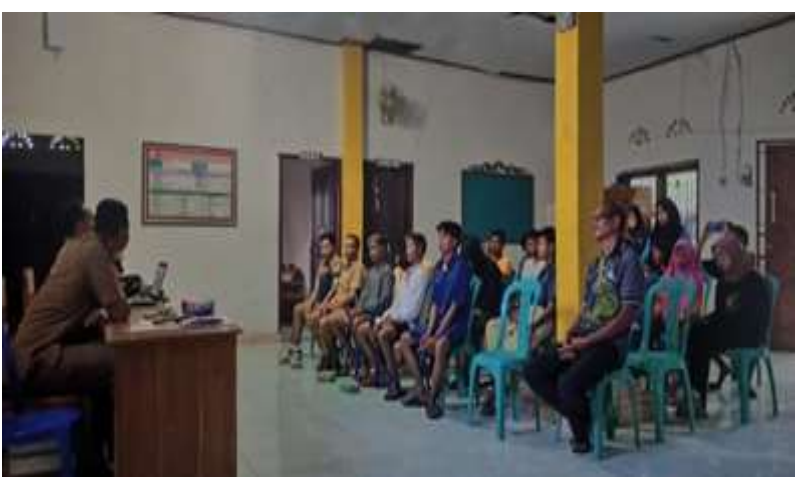

Gambar 6. Kegiatan sosialisasi pengelolaan sampah kepada masyarakat Desa Seriwe

Pada kegiatan sosialisasi, umumnya masyarakat belum memahami cara mengelola sampah dengan baik, namun dengan adanya Sosialisasi bersama dinas tersebut masyarakat lebih memahami arlternatif pengelolaan sampah sehingga dapat ,dampak bencana yang ditimpulkan karena faktor sampah sehingga masyarakat merespon positif dengan dilaksanakannya kegiatan ini.

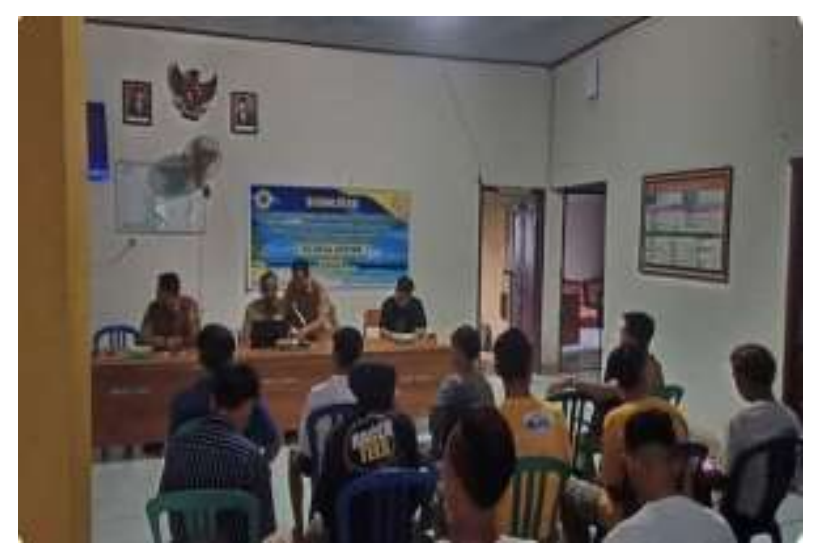

Gambar 7. Kegiatan sosialisasi pengelolaan sampah kepada masyarakat Desa Seriwe

\section{Pengelolaan Sampah Melalui Bank Sampah dan TPS 3R}

a. Penyiapan lahan minimal 4 are (yang memiliki sertifikat yg menyatakan bahwa lahan tersebut merupakan kepemilikan desa).

b. Pembuatan Bank Sampah (tempat berbagai sampah masyarakat ditampung dan diubah mejadi uang maupun barang bermanfaat lainnya) 
c. Apabila sudah ada bank sampah, pemerintah provinsi akan menyediakan bantuan berupa TPS 3R, dengan disediakannya bantuan peralatan seperti mesin pencacah sampah organik dan lain-lain.

\section{Pemilahan Jenis sampah yang terima oleh Bank Sampah}

a. Sampah Anorganik berupa Botol plastik, gelas kaca, Palstik, Kaleng-kaleng, bungkus rokok, bungkus makanan, dan tempat telur, Besi, dan alumunium,

b. Sampah Organik berupa sampah rumput laut.

\section{Pengolahan Biogas dan Pupuk Organik}

\section{a. Biogas}

Biogas merupakan campuran dari berbagai macam gas seperti metana (CH4), karbondioksida (CO2), dan sebagian kecil uap air (H2O), hidrogen sulfida (H2S), dan hidrogen $(\mathrm{H} 2)$. Biogas ini bisa dihasilkan dari sampah-sampah organik seperti sampah dedaunan, kayu, makanan ataupun sampah sayur-sayuran dan buah-buahan dari pasar (Annur, S, 2020).

\section{Langkah-langkah pengolahan sampah menjadi biogas:}

1. Pembangunan tempat pembuatan biogas: didalamnya akan dimasukan berbagai macam sampah organik seperti kotoran hewan dll. (Masyarakat hanya menyediakan bahan, lahan dan peladen untuk pembuatan tempat pengolahan sampah menjadi gas, untuk peralatan seperti kompor dan tukang yang akan membangun akan disediakan oleh pemerintah daerah).

2. Sisa sampah yang telah diolah menjadi gas dapat dimanfaatkan sebagai pupuk.

3. Gas yang dihasilkan dapat dimasukan kedalam genset khusus yang nantinya dapat digunakan sebagai salah satu sumber energi.

\section{b. Pupuk Organik}

Pupuk organik adalah nama kolektif untuk semua jenis bahan organik asal tanaman dan hewan yang dapat dirombak menjadi hara tersedia bagi tanaman (Simanungkalit, R. D. M., 2006). Didesa seriwe, Limbah rumah tangga berupa rumput laut yang telah rusak maupun sampah organic lainnya dapat diolah menjadi pupuk organic yang dapat membantu pertanian masyarakat.
Cara pembuatan pupuk organik diantaranya:

a. Pembuatan Lubang biopori

1. Pembuatan lubang biopori.

2. Sampah organik dimasukan kedalam lubang.

3. Diamkan sampah dilubang selama 2 bulan dan pupuk pun siap digunakan.

b. Sistem Em4:

1. sampah akan difermentasi dengan menggunakan Em4 (Efektif Mikroorganisme) yang dibuat dari campuran air sampah dan air cucian beras

2. sampah dikumpulkan diatas diterpal kemudian di campurkan dengan Em4 yang telah dibuat, 5 liter air, gula merah, dan kotoran hewan.

3. Tutup rapat terpal agar sampah tidak terkena air maupun angin dari luar

4. tunggu sekitar 21 hari.

5. apabila sampah sudah tidak berbau, dan tidak dikerubungi lalat dan magot maka pupuk telah jadi.

6. pupuk yang telah jadi kemudian dikeringkan dan siap digunakan.

c. Sistem Takakura

1. Siapkan karung.

2. Masukan kotoran ternak kering/tanah setinggi $5 \mathrm{~cm}$ kedalam karung

3. Masukan sampah organic.

4. Timbun sampah dengan kotoran ternak kering/tanah sekali lagi.

5. Ikat karung apabila telah penuh.

6. Karung dimasukan kedalam karung semen bekas agar tidak terkena angin maupun air.Tunggu sekitar 1 bulan setengah dan pupuk pun siap digunakan.

Pengelolaan sampah tersebut melibatkan banyak pihak berupa Kepala Desa sebagai penggerak, staf desa, tokoh masyarakat, serta lembaga terkait yang terebntuk demi mewujudkan program tersebut. Sehingga program pendidikan kesadaran bersih lingkungan melalui sosialisasi akan tetap berlanjut ketika Program Kuliah Kerja Nyata telah dilaksanakan. Selain itu, dinas Lingkungan dan Kebersihan turut membantu bila sistem yang jelas telah dibuat seperti ketersediaan lahan, pendataan sampah yang berada di desa. 
Setelah sistem yang jelas dibuat selanjutnya pihak desa akan mengajukan proposal pengajuan bantuan kedinas tersebut, yang apabila disetujui maka bantuan pun akan diberikan. Sehingga untuk memudahkan koordinasi tersebut dapat terebntuk kelembagaan yang terdiri dari pemuda Desa seriwe untuk menjalin koordinasi dan rancangan kerja dalam membangun sarana dan prasarana yang dibutuhkan.

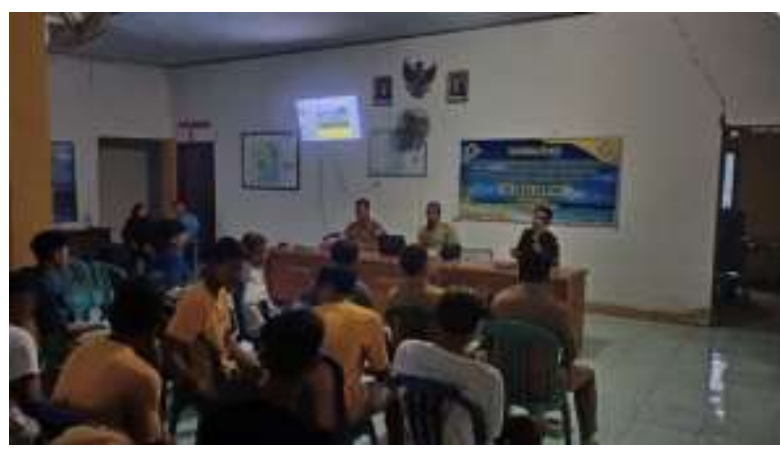

Gambar 8. Sesi Tanya jawab pada kegiatan sosialisasi pengelolaan sampah.

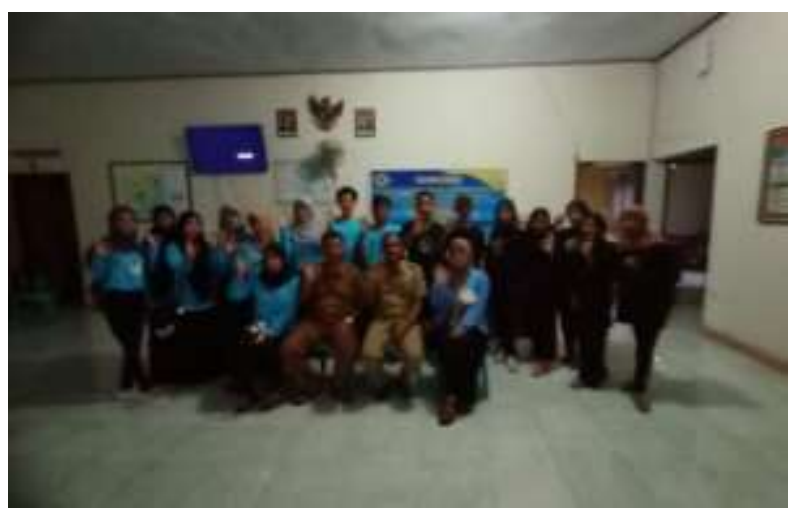

Gambar 9. Kegiatan sosialisasi pengelolaan sampah.

\section{Kesimpulan}

Pengelolaan Sampah adalah hal yang harus dilakukan untuk menanggulangi Bencana yang disebabkan oleh penumpukan Sampah. Maka Pendidikan Kesadaran Sampah dilakukan untuk mempengaruhi masyarakat baik individu, kelompok dan seluruh elemen masyarakat sehingga mereka melakukan pengolahan sampah untuk mewujudkan kawasan yang bersih dan bebas dari sampah. Kegiatan sosialisasi telah memberikan manfaat pada masyarakat. Hal ini dibuktikan dengan bertambahnya wawasan masyarakat mengenai alternative pengolahan sampah sebagai mitigasi bencana dan penunjang ekonomi serta terebntuknya kelembagaan koordinasi dengan pemuda desa seriwe untuk keberlanjutan program tersebut.

\section{Ucapan Terima Kasih}

Kelompok KKN Terpadu UNRAM Desa Seriwe mengucapkan terima kasih kepada Dosen Pembimbing Lapangan Bapak Dr. Drs. Abdul Syukur, M.Si, masyarakat Desa Seriwe dan kepada semua pihak yang terlibat dari awal sampai selesainya sehingga program Kuliah Kerja Nyata ini dapat terlaksana sesuai dengan yang diharapkan.

\section{Daftar Pustaka}

Annur, S., Kusmasari, W., Wulandari, R., \& Sumiati, S. (2020). Pengembangan Biogas dari Sampah untuk Energi Listrik dan Bahan Bakar Kompor di TPA Cilowong, Kota Serang, Banten. KUAT: Keuangan Umum dan Akuntansi Terapan, 2(1), 48-51.

Aris Doyan, Fitri Amelia Putri, Serly Surjan Ekayanti,\& Vandesty Harummiswari H. (2019). Program Pemberdayaan Masyarakat Melalui Pengelolaan Bank Sampah di Desa Montong Baan Kecamatan Sikur Kabupaten Lombok Timur. Jurnal Penabdian Mgister Pendidikan IPA, (1) 2, 50-54.

Gelbert M, Prihanto D, Suprihatin A, (1996) Konsep Pendidikan Lingkungan Hidup dan "Wall Chart". Buku Panduan Pendidikan Lingkungan Hidup, PPPGT/VEDC, Malang

Immy Suci Rohyani, Komang Satria Wirawan Rusady, Muhammad Hafizzudin, Dania Juliani, Ni Wayan Yusvika Yanti, Baiq Karina Permatasari, Ratih Ratna Putri, Luthfiana Safhira Avanda, Fatma Hardianti Sangian, Ni Luh Wulan Sri Apsari, Ni Kadek Sri Wulandari, Wanda Yuliandini, Elinda Sari, Dita Dwi Angraeni, Iin Marya Rizka, \& Baiq Mia Rosdiana. (2021). Pelatihan Pengolahan Sampah berbasis Masyarakat Sebagai Alternatif Penanganan Limbah di Desa Penimbung. Jurnal Pengabdian Magister Pendidikan IPA, 4(4), 410-414.

Kuswardini, S., \& Suprapto, R. A. (2018). Pengelolaan sampah kawasan sungai bengawan solo. In Prosiding Seminar Hasil Pengabdian Masyarakat. (vol. 1, no. 1, pp. 289-294). Yogyakarta: UNIVERSITAS AMIKOM Yogyakarta. 
Mertha, I. G., Rizkiawan, H., Satriadi, A., \& Waskito, P. S. (2020). Sosialisasi Pennanggulangan Sampah Melalui Pendekatan Zero Waste di awasan Wisata Savana Propok Lombok Timur. Jurnal Pengabdian Magister Pendidikan IPA, 3(1).

Purnomo, C.W. (2020). Solusi Pengelolaan Sampah Kota. D.I. Yogyakarta : Gadjah Mada University Press.

S. Hadiwiyoto (1983). Penanganan dan Pemanfaatan Sampah, Jakarta: Yayasan Idayu

Simanungkalit, R. D. M., Suriadikarta, D. A., Saraswati, R., Setyorini, D., \& Hartatik, W. (2006). Pupuk organik dan pupuk hayati.

Tuslaela, T. (2017). KAJIAN PENERAPAN EPROCUREMENT DENGAN METODE KUALITATIF DESKRIPTIF KOMPARATIF PADA PT. PEMBANGUNAN JAYA ANCOL TBK. PROSISKO: Jurnal Pengembangan Riset dan Observasi Sistem Komputer, 4(2).

Wacano, D., Rif'an, A. A., Yuniastuti, E., Daulay, R. W., \& Marfai, M. A. (2013). Adaptasi masyarakat pesisir Kabupaten Demak dalam menghadapi perubahan iklim dan bencana wilayah kepesisiran. Yogyakarta: Percetakan Kanisius Yogyakarta September.

Yana, L. F., Husin, A., \& Hakim, I. A. (2019). Kebiasaan hidup bersih dan sehat pada anak usia dini di kampung 1 Desa Muara Beliti Baru Kabupaten Musi Rawas. Jurnal Pendidikan dan Pemberdayaan Masyarakat (JPPM), 6(1), 4556. 